\title{
Development of a Semiselective Medium for Detection of Nalanthamala psidii, Causal Agent of Wilt of Guava
}

C. F. Hong, H. Y. Hsieh, and C. T. Chen, Fengshan Tropical Horticultural Experiment Branch, Taiwan Agricultural Research Institute, Fengshan 83052, Kaohsiung, Taiwan; and H. C. Huang, Emeritus Principal Research Scientist, Agriculture and Agri-Food Canada, Lethbridge, Alberta, Canada

\begin{abstract}
Hong, C. F., Hsieh, H. Y., Chen, C. T., and Huang, H. C. 2013. Development of a semiselective medium for detection of Nalanthamala psidii, causal agent of wilt of guava. Plant Dis. 97:1132-1136.

Guava wilt, caused by Nalanthamala psidii, has become an important disease of guava (Psidium guajava) in Taiwan since the 1970s. This study was conducted to develop a semiselective medium for detecting $N$. psidii in soil and in tissues of diseased guava trees. Among 9 carbon and 21 nitrogen compounds tested in a modified Czapek-Dox medium, the most effective carbon and nitrogen sources for mycelial growth of N. psidii were sucrose and glycine, respectively. Among eight fungicides tested, iprodione at $5 \mu \mathrm{g} \mathrm{ml}^{-1}$ and azoxystrobin at $1 \mu \mathrm{g} \mathrm{ml}^{-1}$ were the most effective fungicides for detection of $N$. psidii in artificially infested soil or in naturally infected guava debris. Based on the requirement for carbon and nitrogen sources and response to fungicides, a semiselective medium designated as modified sucrose-glycine semi-

selective medium (mSGSSM) was developed for isolation of N. psidii, using the modified Czapek-Dox medium containing 3\% sucrose, $0.3 \%$ glycine, iprodione at $5 \mu \mathrm{g} \mathrm{ml}^{-1}$, azoxystrobin at $1 \mu \mathrm{g} \mathrm{ml}^{-1}$, streptomycin at $200 \mu \mathrm{g} \mathrm{ml}^{-1}$, and neomycin at $200 \mu \mathrm{g} \mathrm{ml}^{-1}$. Colonies of $N$. psidii on mSGSSM at $30^{\circ} \mathrm{C}$ for 5 to 10 days were white to orange with sparse aerial hyphae. $N$. psidii was detected more accurately and efficiently on mSGSSM than on other media, including potato dextrose agar, modified Nash-Snyder medium, and modified Czapek-Dox medium. This semiselective medium is effective in detection of $N$. psidii from various parts of diseased guava trees and in soil; therefore, it would be a useful medium for etiological, ecological, and epidemiological studies of guava wilt.
\end{abstract}

Guava (Psidium guajava L.) is an important fruit crop in the tropical region of Central and South America and South Africa as well as South and Southeast Asia. In Taiwan, the area for guava production is about 6,900 ha, mainly distributed in the central and southern regions, including Changhua County, Tainan City, and Kaohsiung City (1). Guava wilt, caused by Nalanthamala psidii (Sawada \& Kuros.) Schroers \& M.J. Wingf. (syn. Myxosporium psidii Sawada \& Kuros.) (11), was first reported in Taiwan as "Tachigare Byo" by Kurosawa in 1926 (5). It has caused serious losses of guava production in Taiwan since the 1970s $(3,7)$.

Leu et al. (6) reported that $N$. psidii infected guava plants through wounds created by pruning and trimming. After infection of wounded twigs, the pathogen spreads from the initial infection site to other plant tissues, including the main stem and roots, causing symptoms of defoliation, wilt, and eventually death of the entire tree. Therefore, treatment of wounded sites with fungicides or replanting of healthy guava seedlings after removal of diseased trees was suggested for control of guava wilt because the pathogen could not survive in the soil (6). In contrast, Lim and Manicom (8) reported that spraying fungicides on pruning wounds was rarely effective for the control of guava wilt in South Africa. Meanwhile, several reports $(5,8,10)$ proposed that the root and basal stem of guava were the primary infection sites of $N$. psidii. These conflict-

Corresponding author: C. F. Hong, E-mail: cfhong @fthes-tari.gov.tw

Current address of H. C. Huang: Plant Pathology Division, Taiwan Agricultural Research Institute, Wufeng, Taichung, Taiwan.

Accepted for publication 7 March 2013.

http://dx.doi.org/10.1094/PDIS-12-12-1193-RE

(c) 2013 The American Phytopathological Society ing conclusions which described initial infection and spread of $N$. psidii in host tissues $(5,6,8)$ may be due to differences in the ability to isolate $N$. psidii from soil and infected plants. Therefore, accurate isolation and detection methods are critical for etiological and ecological studies of $N$. psidii. The objective of this study was to develop a semiselective medium for effective and efficient detection of $N$. psidii in diseased tissues of guava plants and in N. psidiiinfested soil.

\section{Materials and Methods}

Isolation and maintenance of $N$. psidii. Isolates of N. psidii were collected from diseased branches and stumps of guava plants from 2008 to 2012. Each isolate was single spored and tested for pathogenicity on guava plants to fulfill Koch's postulates. Three of the N. psidii isolates (Mp-01, Mp-02, and $\mathrm{Mp}-03$ ) obtained from Yanchao District, Qishan District, and Fengshan District of Kaohsiung City, respectively, were used in this study (Table 1). Working cultures were maintained on a modified Czapek-Dox medium (mCDM) (2) at $25^{\circ} \mathrm{C}$ under $12 \mathrm{~h}$ of illumination daily. Stock cultures were prepared by growing each isolate of $N$. psidii on a sand-agar medium ( 0.8 to $1 \%$ water agar $+10 \%$ sandy loam) at $30^{\circ} \mathrm{C}$ for 3 days and then storing at $4{ }^{\circ} \mathrm{C}$ in the dark.

Effect of carbon source on mycelial growth of $N$. psidii. Nine compounds, including fructose, galactose, glucose, lactose, mannitol, mannose, soluble starch, sucrose, and xylose, were tested for the effect of carbon sources on mycelial growth of $N$. psidii using mCDM without sucrose (mCDM-C) as a basal medium. The amount of each carbon source used to replace the sucrose in $\mathrm{mCDM}$ was $3 \%$. Agar discs (5 $\mathrm{mm}$ in diameter) containing mycelial mats of each of the three isolates (Mp-01, Mp-02, and Mp-03) were removed from 7-day-old $\mathrm{mCDM}$ cultures and placed at the center of each carbon-amended mCDM-C in petri dishes $(9 \mathrm{~cm}$ in diameter), one disc per dish and five dishes per isolate. For controls, agar discs (5 $\mathrm{mm}$ in diameter) containing mycelial mats of 
each isolate were inoculated on $\mathrm{mCDM}-\mathrm{C}$, one disc per dish and five dishes per isolate. Colony diameter of each dish was measured after incubation at $30^{\circ} \mathrm{C}$ for 7 days. The experiment was repeated once.

Effect of nitrogen source on mycelial growth of $N$. psidii. The mCDM containing $3 \%$ sucrose without sodium nitrate (mCDM-N) was used as a basal medium for testing the effect of nitrogen compounds on mycelial growth of $N$. psidii. Each of the 21 nitrogen compounds (Table 2) was added to the mCDM-N at $0.3 \%$. The three isolates of $N$. psidii described previously were tested for mycelial growth on each nitrogen-amended mCDM-N medium using the same procedure described in the carbon source experiment. Cultures grown on mCDM-N were used as controls. The experiment was repeated once.

Effect of fungicides on mycelial growth of $\boldsymbol{N}$. psidii. Based on the requirements of carbon source and nitrogen source for $N$. psidii, a basal medium, sucrose-glycine medium (SGM), was used to test the effects of eight commercial fungicides, including azoxystrobin (Syngenta), carbendazim (TFA), dithianon (BASF), etridiazole (Chemtura Co.), iprodione (BYER), prochloraz (VAPCO), procymidone (VAPCO), and thiabendazole (TFA), on mycelial growth of $N$. psidii. The ingredients of SGM were $30 \mathrm{~g}$ of sucrose, $3 \mathrm{~g}$ of glycine, $1 \mathrm{~g}$ of $\mathrm{K}_{2} \mathrm{HPO}_{4}, 0.5 \mathrm{~g}$ of $\mathrm{MgSO}_{4} 7 \mathrm{H}_{2} \mathrm{O}, 0.5$ $\mathrm{g}$ of $\mathrm{KCl}, 0.01 \mathrm{~g}$ of $\mathrm{FeSO}_{4} 7 \mathrm{H}_{2} \mathrm{O}, 15 \mathrm{~g}$ of agar, and 1 liter of distilled water.

The SGM was adjusted to $\mathrm{pH} 6$ using $1 \mathrm{~N} \mathrm{HCl}$, autoclaved at $121^{\circ} \mathrm{C}$ for $15 \mathrm{~min}$, and amended with each of the eight fungicides when the temperature of the medium had cooled to 45 to $50^{\circ} \mathrm{C}$. Two concentrations, 1 and $5 \mu \mathrm{g} \mathrm{ml}^{-1}$, were used for each fungicide. The three isolates of $N$. psidii were tested on fungicide-amended SGM for mycelial growth by the procedure described in the carbon-source experiment. The fungicides with high toxicity to nontarget microbes but low toxicity to $N$. psidii were selected for further development of the semiselective medium. The experiment was repeated three times.

Effect of fungicides on mycelial growth of saprophytes. To test the effect of different fungicides on mycelial growth of saprophytes in soil and diseased tissues, several fungi (soil saprophytes or guava pathogens) were used, including an Aspergillus sp., Colletotrichum sp., Fusarium sp., Pestalotiopsis sp., Trichoderma sp., and Ascochyta melonis (isolate BCRC 32122, purchased from Food Industry Research and Development Institute, Taiwan); each fungus had one isolate (Table 1). Among these fungi, the Aspergillus sp., Fusarium sp., and Trichoderma sp. were obtained from soil while the Colletotrichum sp. and Pestalotiopsis sp. were obtained from diseased guava fruit. These fungal isolates were cultured on potato dextrose agar (PDA) at $28^{\circ} \mathrm{C}$ for 7 days under $12 \mathrm{~h}$ of illumination. Agar discs (5 $\mathrm{mm}$ in diameter) containing mycelial mats of each of the fungi were placed at the center of fungicideamended SGM in each petri dish ( $9 \mathrm{~cm}$ in diameter), one disc per dish and three dishes per fungal isolate. SGM without any fungicide and modified sucrose-glycine semiselective medium (mSGSSM) were used as controls. Colony diameters of all the cultures were measured after incubation at $30^{\circ} \mathrm{C}$ for 7 days, except for the cultures of the Trichoderma sp., which were incubated at $30^{\circ} \mathrm{C}$ for 4 days. The experiment was repeated twice.
Preparation of $N$. psidii-infested soil. Soil infested with $N$. psidii isolate $\mathrm{Mp}-02$ or $\mathrm{Mp}-03$ was prepared by modification of the method described by Huang et al. (4). To prepare inoculum of each isolate of $N$. psidii, agar plugs $(5 \mathrm{~mm}$ in diameter) containing mycelial mats were removed from 7- to 14-day-old cultures, placed on autoclaved stem segments of celery in 500-ml flasks with five agar plugs per $200 \mathrm{~g}$ of celery per flask, and incubated at $30^{\circ} \mathrm{C}$ for 7 to 14 days for complete colonization of celery stem segments by the pathogen. The $N$. psidii-colonized celery stem segments were mixed with autoclaved sandy loam soil ( $\mathrm{sand} / \mathrm{loam}=1: 9, \mathrm{vol} / \mathrm{vol})$ at $200 \mathrm{~g}$ of celery stems per 2 liters of soil. The $N$. psidii-infested soil was incubated at $30^{\circ} \mathrm{C}$ for 14 to 21 days, sieved through a 14mesh screen, and stored in a plastic bag at room temperature (27 to $32^{\circ} \mathrm{C}$ ) until used in the experiments.

Detection of $N$. psidii in soil and diseased tissues by modified SG-semiselective medium. The mSGSSM was prepared using SGM as a basal medium. The SGM was adjusted to $\mathrm{pH} 6$ using $1 \mathrm{~N}$ $\mathrm{HCl}$, autoclaved at $121^{\circ} \mathrm{C}$ for $15 \mathrm{~min}$, cooled to 45 to $50^{\circ} \mathrm{C}$, and then the following were added: iprodione at $5 \mu \mathrm{g} \mathrm{ml} \mathrm{m}^{-1}$, azoxystrobin at $1 \mu \mathrm{g} \mathrm{ml}^{-1}$, neomycin at $200 \mu \mathrm{g} \mathrm{ml}^{-1}$, and streptomycin at $200 \mu \mathrm{g} \mathrm{ml}^{-1}$. To test the effectiveness of mSGSSM, the soil artificially infested with $N$. psidii was mixed with the natural

Table 2. Effect of nitrogen source on mycelial growth of Nalanthamala psidii (isolates Mp-01, Mp-02, and Mp-03)

\begin{tabular}{|c|c|c|c|}
\hline \multirow[b]{2}{*}{ Nitrogen source $^{\mathrm{z}}$} & \multicolumn{3}{|c|}{ Colony diameter $(\mathbf{m m})^{y}$} \\
\hline & Мp-01 & Мp-02 & Mp-03 \\
\hline$\left(\mathrm{NH}_{4}\right)_{2} \mathrm{CO}_{3}$ & $66.3 \mathrm{~b}$ & $81.3 \mathrm{a}$ & $80.6 \mathrm{a}$ \\
\hline $\mathrm{NH}_{4} \mathrm{NO}_{3}$ & $56.5 \mathrm{fg}$ & $58.3 \mathrm{fgh}$ & $50.0 \mathrm{gh}$ \\
\hline$\left(\mathrm{NH}_{4}\right)_{2} \mathrm{HPO}_{4}$ & 60.0 cde & $74.0 \mathrm{bc}$ & $72.7 \mathrm{~cd}$ \\
\hline $\mathrm{NH}_{4} \mathrm{H}_{2} \mathrm{PO}_{4}$ & $67.6 \mathrm{~b}$ & $71.0 \mathrm{~cd}$ & $79.4 \mathrm{ab}$ \\
\hline$\left(\mathrm{NH}_{4}\right)_{2} \mathrm{SO}_{4}$ & $53.7 \mathrm{gh}$ & $50.1 \mathrm{i}$ & $48.1 \mathrm{~h}$ \\
\hline $\mathrm{KNO}_{3}$ & $58.8 \mathrm{c}-\mathrm{f}$ & $63.6 \mathrm{ef}$ & $68.9 \mathrm{~cd}$ \\
\hline $\mathrm{NaNO}_{3}$ & $59.4 \mathrm{c}-\mathrm{f}$ & $59.8 \mathrm{fg}$ & $68.1 \mathrm{~cd}$ \\
\hline $\mathrm{NaNO}_{2}$ & $59.4 \mathrm{c}-\mathrm{f}$ & $57.7 \mathrm{gh}$ & $66.5 \mathrm{de}$ \\
\hline Arginine & $38.6 \mathrm{i}$ & $42.9 \mathrm{jk}$ & $54.7 \mathrm{fg}$ \\
\hline Asparagine & $68.6 \mathrm{~b}$ & $78.5 \mathrm{ab}$ & $84.4 \mathrm{a}$ \\
\hline Casein & $52.2 \mathrm{~h}$ & $62.5 \mathrm{efg}$ & $84.3 \mathrm{a}$ \\
\hline Cysteine & $29.7 \mathrm{j}$ & $37.9 \mathrm{k}$ & $48.4 \mathrm{gh}$ \\
\hline Glycine & $74.3 \mathrm{a}$ & $83.7 \mathrm{a}$ & $85.0 \mathrm{a}$ \\
\hline Methionine & $56.6 \mathrm{fg}$ & $74.3 \mathrm{bc}$ & $74.2 \mathrm{bc}$ \\
\hline Peptone & $61.2 \mathrm{c}$ & $67.5 \mathrm{de}$ & $79.0 \mathrm{ab}$ \\
\hline Phenylalanine & $50.7 \mathrm{~h}$ & $53.2 \mathrm{hi}$ & $69.1 \mathrm{~cd}$ \\
\hline Proline & 57.8 ef & $65.3 \mathrm{e}$ & $67.1 \mathrm{~d}$ \\
\hline Tryptophan & $38.3 \mathrm{i}$ & 32.01 & $60.0 \mathrm{f}$ \\
\hline Tyrosine & $58.1 \mathrm{def}$ & $62.4 \mathrm{efg}$ & 60.8 ef \\
\hline Urea & $36.6 \mathrm{i}$ & $48.0 \mathrm{ij}$ & $49.3 \mathrm{gh}$ \\
\hline Yeast extract & $66.2 \mathrm{~b}$ & $62.3 \mathrm{efg}$ & $84.9 \mathrm{a}$ \\
\hline Control & $61.2 \mathrm{~cd}$ & $72.8 \mathrm{~cd}$ & $81.1 \mathrm{a}$ \\
\hline
\end{tabular}

y Cultures of $N$. psidii were incubated at $30^{\circ} \mathrm{C}$ for 7 days and measured for colony diameter. Means $(n=10)$ followed by the same letter within each column are not significantly different according to Fisher's protected least significant difference test at $P=0.05$.

${ }^{\mathrm{z}}$ Modified Czapek-Dox medium (mCDM) containing 3\% (wt/vol) sucrose was used as a basal medium for testing each nitrogen source $(0.3 \%$ [wt/vol] $)$. Control = mCDM containing 3\% (wt/vol) sucrose only.

Table 1. List of the origin, host or substrate, and year of collection of the microorganisms tested in this study

\begin{tabular}{lll}
\hline Microorganism & Origin & Host, substrate ${ }^{\mathbf{z}}$ \\
\hline Ascochyta melonis BCRC 32122 & FIRDI, Taiwan & Year \\
Aspergillus sp. & Fengshan & Citrulus vulgaris Schrad. \\
Colletotrichum sp. & Fengshan & Soil \\
Fusarium sp. & Fengshan & Psidium guajava L., diseased fruit \\
Nalanthamala psidii Mp-01 & Yanchao & Soil \\
N. psidii Mp-02 & Qishan & P. guajava, diseased limb \\
N. psidii Mp-03 & Fengshan & P. guajava, diseased limb \\
Pestalotiopsis sp. & Gaoshu & P. guajava, diseased limb \\
Trichoderma sp. & Fengshan & Puajava, diseased fruit \\
\hline
\end{tabular}

y FIRDI = Food Industry Research and Development Institute, Hsinchu, Taiwan.

${ }^{\mathrm{z}}$ Host or substrate where the microorganisms were obtained. 
soil collected from a guava orchard at 1:1 (vol/vol). The pathogeninfested soil was used to prepare a soil suspension by mixing $5 \mathrm{ml}$ of the soil with $45 \mathrm{ml}$ of sterile distilled water. This soil suspension was serially diluted to $10^{-3}$. Each soil suspension was spread on mSGSSM in petri dishes, $100 \mu \mathrm{l}$ per dish, and the dishes were examined for colonies of $N$. psidii after incubation at $30^{\circ} \mathrm{C}$ for 7 days. To test colony development of $N$. psidii on other media, the same amount of each soil dilution was spread on PDA (Difco), mCDM, and modified Nash-Snyder medium (mNSM) (9). There

Table 3. Effect of carbon source on mycelial growth of Nalanthamala psidii (isolates Mp-01, Mp-02, and Mp-03)

\begin{tabular}{lccl}
\hline & \multicolumn{3}{c}{${\text { Colony diameter }(\mathbf{m m})^{\mathbf{y}}}$ Carbon source $^{\mathbf{z}}$} \\
\cline { 2 - 4 } & Mp-01 & Mp-02 & Mp-03 \\
\hline Fructose & $47.4 \mathrm{~d}$ & $45.5 \mathrm{~d}$ & $62.6 \mathrm{~b}$ \\
Galactose & $48.5 \mathrm{~cd}$ & $51.1 \mathrm{c}$ & $69.1 \mathrm{a}$ \\
Glucose & $52.6 \mathrm{c}$ & $53.2 \mathrm{c}$ & $69.1 \mathrm{a}$ \\
Lactose & $34.4 \mathrm{f}$ & $38.6 \mathrm{e}$ & $45.9 \mathrm{~d}$ \\
Mannitol & $58.3 \mathrm{ab}$ & $60.0 \mathrm{ab}$ & $65.7 \mathrm{ab}$ \\
Mannose & $57.5 \mathrm{~b}$ & $55.6 \mathrm{bc}$ & $69.7 \mathrm{a}$ \\
Sucrose & $62.2 \mathrm{a}$ & $62.0 \mathrm{a}$ & $67.3 \mathrm{a}$ \\
Soluble starch & $38.8 \mathrm{e}$ & $41.9 \mathrm{de}$ & $50.3 \mathrm{c}$ \\
Xylose & $34.1 \mathrm{f}$ & $33.2 \mathrm{f}$ & $49.6 \mathrm{~cd}$ \\
Control & $58.0 \mathrm{~b}$ & $60.1 \mathrm{ab}$ & $62.6 \mathrm{~b}$ \\
\hline
\end{tabular}

${ }^{y}$ Cultures of $N$. psidii were incubated at $30^{\circ} \mathrm{C}$ for 7 days and measured for colony diameter. Means $(n=10)$ followed by the same letter within each column are not significantly different according to Fisher's protected least significant difference test at $P=0.05$.

${ }^{\mathrm{z}}$ Modified Czapek-Dox medium (mCDM) containing 0.3\% (wt/vol) sodium nitrate was used as a basal medium for testing each carbon source $(3 \%[\mathrm{wt} / \mathrm{vol}])$. Control $=\mathrm{mCDM}$ containing $0.3 \%(\mathrm{wt} / \mathrm{vol})$ sodium nitrate only. were five petri dishes for each treatment and the experiment was repeated once.

To test the effectiveness of mSGSSM for isolation of $N$. psidii, woody limbs or roots of wilted guava plants were collected from orchards in Yilan County (three limbs from different trees), Yunlin County (two limbs from different trees), Miaoli County (one limb), and Kaohsiung City (one limb and the roots from one mature tree). Diseased tissues were surface sterilized with $75 \%$ ethanol for 10 to $15 \mathrm{~s}$, excised from one area of the limb or the root, split into four pieces, and then randomly placed on mSGSSM, PDA, mCDM, and $\mathrm{mNSM}$ in petri dishes $(9 \mathrm{~cm}$ in diameter). The same procedure was used for detection of $N$. psidii in other area of diseased limb or root tissues. All of the petri dishes were incubated at $30^{\circ} \mathrm{C}$ for 5 to 7 days and the numbers of $N$. psidii colonies in each dish were recorded. Meanwhile, colony color of $N$. psidii on mSGSSM was determined using The Royal Horticultural Society (RHS) color chart.

Statistical analysis. Data of radial mycelial growth of $N$. psidii in each experiment were pooled and analyzed using analysis of variance in SAS Enterprise Guide (version 4.1; SAS Institute) for a completely randomized design. Treatment means for each run of the experiments on carbon source, nitrogen source, and fungicide were compared using Fisher's protected least significant difference test $(P=0.05)$.

\section{Results}

Effect of carbon and nitrogen sources on mycelial growth of $N$. psidii. Depending on the isolate, amendment of mCDM-C medium with sucrose, mannitol, or mannose as a carbon source resulted in a significant $(P<0.05)$ increase or no significant effect on colony diameter of $N$. psidii (Table 3) when compared with the control. In contrast, amendment of mCDM-C medium with fruc-

Table 4. Effect of fungicides on mycelial growth of Nalanthamala psidii on sucrose-glycine medium (SGM)

\begin{tabular}{|c|c|c|c|c|c|c|}
\hline \multirow[b]{3}{*}{ Chemicals } & \multicolumn{6}{|c|}{ Mycelial growth $(\mathbf{m m})^{\mathrm{z}}$} \\
\hline & \multicolumn{2}{|c|}{ Isolate Mp-01 } & \multicolumn{2}{|c|}{ Isolate Mp-02 } & \multicolumn{2}{|c|}{ Isolate Mp-03 } \\
\hline & 5 & 1 & 5 & 1 & 5 & 1 \\
\hline Azoxystrobin & $18.8 \mathrm{e}$ & $29.7 \mathrm{e}$ & $23.0 \mathrm{~d}$ & $33.9 \mathrm{e}$ & $26.1 \mathrm{~d}$ & $34.5 \mathrm{~d}$ \\
\hline Carbendazim & $0.0 \mathrm{f}$ & $0.0 \mathrm{f}$ & $0.0 \mathrm{e}$ & $0.0 \mathrm{f}$ & $0.0 \mathrm{e}$ & $0.0 \mathrm{e}$ \\
\hline Dithianon & $28.0 \mathrm{~d}$ & $60.1 \mathrm{bc}$ & $30.6 \mathrm{c}$ & $49.8 \mathrm{~d}$ & $33.9 \mathrm{c}$ & $51.7 \mathrm{c}$ \\
\hline Etridiazole & $73.6 \mathrm{a}$ & $74.2 \mathrm{a}$ & $75.1 \mathrm{a}$ & $75.2 \mathrm{a}$ & $77.0 \mathrm{a}$ & $78.2 \mathrm{a}$ \\
\hline Iprodione & $26.1 \mathrm{~d}$ & $51.9 \mathrm{~d}$ & $28.1 \mathrm{c}$ & $56.3 \mathrm{c}$ & $30.2 \mathrm{~cd}$ & $57.9 \mathrm{c}$ \\
\hline Prochloraz & $0.0 \mathrm{f}$ & $0.0 \mathrm{f}$ & $0.0 \mathrm{e}$ & $0.0 \mathrm{f}$ & $0.0 \mathrm{e}$ & $0.0 \mathrm{e}$ \\
\hline Procymidone & $34.3 \mathrm{c}$ & $50.2 \mathrm{~d}$ & $41.5 \mathrm{~b}$ & $64.7 \mathrm{~b}$ & $41.5 \mathrm{~b}$ & $65.3 \mathrm{~b}$ \\
\hline Thiabendazole & $0.0 \mathrm{f}$ & $52.6 \mathrm{~cd}$ & $0.0 \mathrm{e}$ & $64.4 \mathrm{~b}$ & $0.0 \mathrm{e}$ & $67.6 \mathrm{~b}$ \\
\hline Control & $65.8 \mathrm{~b}$ & $65.8 \mathrm{~b}$ & $78.6 \mathrm{a}$ & $78.6 \mathrm{a}$ & $78.9 \mathrm{a}$ & $78.9 \mathrm{a}$ \\
\hline
\end{tabular}

${ }^{\mathrm{z}}$ Mycelial growth of $N$. psidii was determined after the cultures were incubated at $30^{\circ} \mathrm{C}$ for 7 days. Concentrations of each fungicide in SGM were 5 and 1 $\mu \mathrm{g} \mathrm{ml}{ }^{-1}$ a.i. Means $(n=20)$ followed by the same letter within each column are not significantly different according to Fisher's protected least significant difference test at $P=0.05$.

Table 5. Effect of different fungicides on mycelial growth of six fungi isolated from soil and guava tissues

\begin{tabular}{|c|c|c|c|c|c|c|c|c|c|c|c|c|}
\hline \multirow[b]{3}{*}{ Chemicals } & \multicolumn{12}{|c|}{ Mycelial growth $(\mathbf{m m})^{y}$} \\
\hline & \multicolumn{2}{|c|}{ Ascochyta melonis } & \multicolumn{2}{|c|}{ Aspergillus sp. } & \multicolumn{2}{|c|}{ Colletotrichum sp. } & \multicolumn{2}{|c|}{ Fusarium sp. } & \multicolumn{2}{|c|}{ Pestalotiopsis sp. } & \multicolumn{2}{|c|}{ Trichoderma sp. } \\
\hline & 5 & 1 & 5 & 1 & 5 & 1 & 5 & 1 & 5 & 1 & 5 & 1 \\
\hline Azoxystrobin & $33.1 \mathrm{~b}$ & $29.6 \mathrm{~b}$ & $53.9 \mathrm{~b}$ & $59.3 \mathrm{a}$ & $60.2 \mathrm{~b}$ & $63.3 \mathrm{c}$ & $30.5 \mathrm{~d}$ & $40.4 \mathrm{~d}$ & $0.0 \mathrm{f}$ & $3.0 \mathrm{~d}$ & $78.9 \mathrm{~b}$ & $77.2 \mathrm{c}$ \\
\hline Carbendazim & $0.0 \mathrm{c}$ & $0.0 \mathrm{e}$ & $0.0 \mathrm{f}$ & $0.0 \mathrm{e}$ & $13.0 \mathrm{f}$ & $14.6 \mathrm{f}$ & $0.0 \mathrm{f}$ & $1.8 \mathrm{~g}$ & $49.6 \mathrm{a}$ & $48.7 \mathrm{a}$ & $0.0 \mathrm{f}$ & $9.7 \mathrm{~g}$ \\
\hline Dithianon & $26.1 \mathrm{~b}$ & $48.0 \mathrm{a}$ & $35.3 \mathrm{c}$ & $59.8 \mathrm{a}$ & $56.4 \mathrm{c}$ & $74.9 \mathrm{~b}$ & $54.8 \mathrm{~b}$ & $67.9 \mathrm{ab}$ & $28.9 \mathrm{c}$ & $48.7 \mathrm{a}$ & $68.4 \mathrm{c}$ & $82.6 \mathrm{ab}$ \\
\hline Etridiazole & $51.1 \mathrm{a}$ & $46.8 \mathrm{a}$ & $69.4 \mathrm{a}$ & $59.2 \mathrm{a}$ & $85.0 \mathrm{a}$ & $85.0 \mathrm{a}$ & $65.8 \mathrm{a}$ & $72.1 \mathrm{a}$ & $45.8 \mathrm{a}$ & $49.7 \mathrm{a}$ & $80.7 \mathrm{ab}$ & $85.0 \mathrm{a}$ \\
\hline Iprodione & $5.2 \mathrm{c}$ & $13.5 \mathrm{cde}$ & $13.4 \mathrm{de}$ & $22.3 \mathrm{c}$ & $45.4 \mathrm{~d}$ & $72.3 \mathrm{~b}$ & $29.5 \mathrm{~d}$ & $59.0 \mathrm{c}$ & $9.9 \mathrm{e}$ & $33.4 \mathrm{c}$ & $10.3 \mathrm{e}$ & $37.5 \mathrm{~d}$ \\
\hline Prochloraz & $11.2 \mathrm{c}$ & $18.2 \mathrm{bcd}$ & $0.0 \mathrm{f}$ & $0.0 \mathrm{e}$ & $0.0 \mathrm{~g}$ & $2.6 \mathrm{~g}$ & $0.0 \mathrm{f}$ & $7.8 \mathrm{f}$ & $0.0 \mathrm{f}$ & $5.9 \mathrm{~d}$ & $0.0 \mathrm{f}$ & $2.1 \mathrm{~h}$ \\
\hline Procymidone & $10.7 \mathrm{c}$ & $29.4 \mathrm{~b}$ & $11.0 \mathrm{e}$ & $18.8 \mathrm{~cd}$ & $60.6 \mathrm{~b}$ & $81.4 \mathrm{a}$ & $43.4 \mathrm{c}$ & $65.8 \mathrm{~b}$ & $20.4 \mathrm{~d}$ & $39.4 \mathrm{bc}$ & $28.4 \mathrm{~d}$ & $80.2 \mathrm{bc}$ \\
\hline Thiabendazole & $0.0 \mathrm{c}$ & $22.0 \mathrm{bc}$ & $20.8 \mathrm{~d}$ & $43.4 \mathrm{~b}$ & $20.4 \mathrm{e}$ & $25.0 \mathrm{~d}$ & $0.0 \mathrm{f}$ & $53.9 \mathrm{c}$ & $40.1 \mathrm{~b}$ & $42.8 \mathrm{ab}$ & $10.6 \mathrm{e}$ & $18.3 \mathrm{e}$ \\
\hline SGM & $48.3 \mathrm{a}$ & $48.3 \mathrm{a}$ & $58.7 \mathrm{~b}$ & $60.2 \mathrm{a}$ & $83.9 \mathrm{a}$ & $83.9 \mathrm{a}$ & $68.4 \mathrm{a}$ & $68.4 \mathrm{ab}$ & $45.7 \mathrm{a}$ & $45.7 \mathrm{ab}$ & $85.0 \mathrm{a}$ & $85.0 \mathrm{a}$ \\
\hline mSGSSM $^{z}$ & $5.0 \mathrm{c}$ & $5.0 \mathrm{de}$ & $14.3 \mathrm{de}$ & $13.9 \mathrm{~d}$ & $19.8 \mathrm{e}$ & $19.8 \mathrm{e}$ & $17.5 \mathrm{e}$ & $17.5 \mathrm{e}$ & $0.0 \mathrm{f}$ & $0.0 \mathrm{~d}$ & $13.2 \mathrm{e}$ & $13.6 \mathrm{f}$ \\
\hline
\end{tabular}

${ }_{\mathrm{y}}$ Mycelial growth of each fungus was determined after the cultures were incubated at $30^{\circ} \mathrm{C}$ for 4 (Trichoderma sp.) and 7 (other fungi isolates) days, respectively. Concentrations of each fungicide in sucrose-glycine medium (SGM) were 5 and $1 \mu \mathrm{g} \mathrm{ml}^{-1}$ a.i. Means $(n=9)$ followed by the same letter within each column are not significantly different according to Fisher's protected least significant difference test at $P=0.05$.

${ }^{\mathrm{z}}$ Modified sucrose-glycine semiselective medium. 
tose, galactose, glucose, lactose, soluble starch, or xylose had no effect or significantly $(P<0.05)$ reduced the colony diameter of $N$. psidii. Therefore, sucrose was selected as a carbon source for formulation of the semiselective medium for this pathogen.

Of 21 nitrogen compounds tested, amendment of mCDM-N with $\left(\mathrm{NH}_{4}\right)_{2} \mathrm{CO}_{3}$, asparagine, and glycine resulted in a significant $(P<$ $0.05)$ increase in colony diameter of $N$. psidii isolates Mp-01 and Mp-02 when compared with the control (Table 2). In contrast, amendment of mCDM-N with any of the other 18 nitrogen compounds had no effect or significantly $(P<0.05)$ reduced mycelial growth of $N$. psidii. Among them, glycine was selected for formulation of the semiselective medium in further experiments because of its effectiveness in promoting the colony growth of $N$. psidii (Table 2).

Effect of fungicides on mycelial growth of $N$. psidii and other fungi. Depending on the isolate, etridiazole at $1 \mu \mathrm{g} \mathrm{ml}^{-1}$ and $5 \mu \mathrm{g}$ $\mathrm{ml}^{-1}$ a.i. either significantly $(P<0.05)$ increased or had no effect on mycelial growth of $N$. psidii, compared with the nontreated control on SGM (Table 4). Although etridiazole had no suppressive effect on $N$. psidii, it also showed no suppression of other fungi. Therefore, etridiazole was not suitable for use in the formulation of the semiselective medium (Table 5).

The seven other fungicides, including azoxystrobin, carbendazim, dithianon, iprodione, prochloraz, procymidone, and thiabendazole, all significantly $(P<0.05)$ reduced mycelial growth of $N$. psidii at 1 and $5 \mu \mathrm{g} \mathrm{ml}{ }^{-1}$ a.i. Among them, carbendazim and prochloraz suppressed mycelial growth of $N$. psidii completely at both concentrations (Table 4). Although they also significantly ( $P$ $<0.05)$ suppressed mycelial growth of other fungi, including $A$. melonis and the Aspergillus sp., Colletotrichum sp., Fusarium sp., and Trichoderma sp. (Table 5), carbendazim and prochloraz were excluded from the formulation of the semiselective medium. Thiabendazole and iprodione were more effective than azoxystrobin, dithianon, and procymidone in suppression of mycelial growth of nontarget fungi. Although thiabendazole showed a greater effect in reducing mycelial growth of A. melonis, Colletotrichum sp., and Fusarium sp. than iprodione at $5 \mu \mathrm{g} \mathrm{ml}^{-1}$ a.i. (Table 5), it also completely inhibited mycelial growth of N. psidii (Table 4). Azoxystrobin was the most toxic fungicide to the Pestalotiopsis sp., a

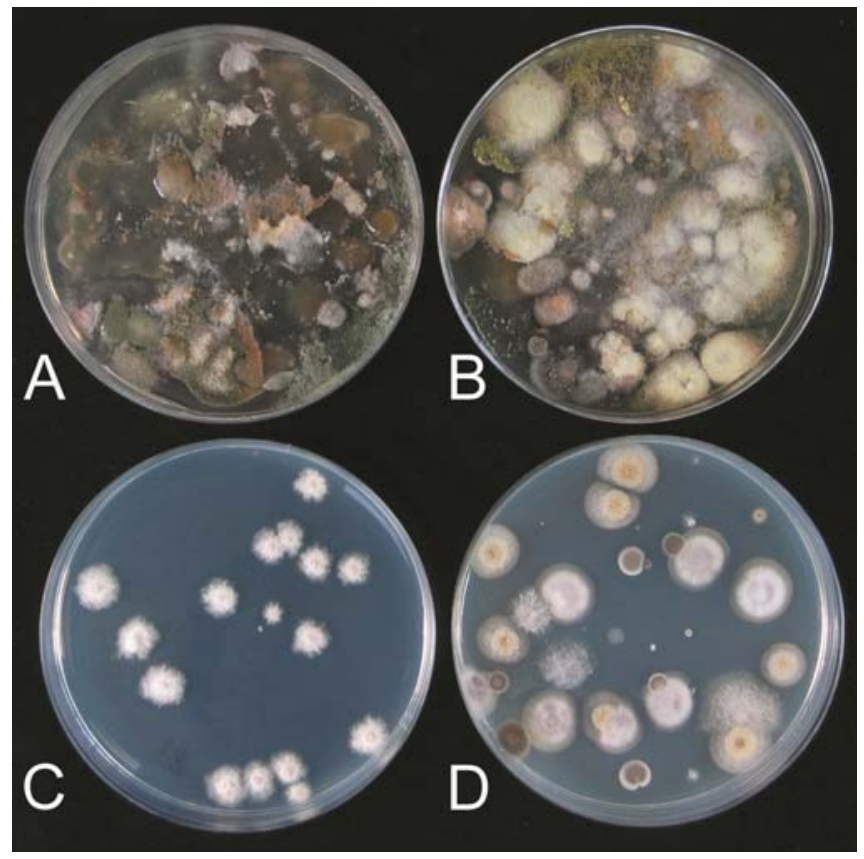

Fig. 1. Isolation of Nalanthamala psidii from soil using A, potato dextrose agar; $\mathbf{B}$, modified Czapek-Dox medium; C, modified sucrose-glycine semiselective medium (mSGSSM); and D, modified Nash-Snyder medium. Soil samples collected from a guava field were artificially infested with $N$. psidii. Cultures were incubated at $30^{\circ} \mathrm{C}$ for 7 days. Note that all the white colonies on mSGSSM medium (C) are N. psidii. common fungus on guava twigs, limbs, and fruit. Therefore, iprodione at $5 \mu \mathrm{g} \mathrm{ml}^{-1}$ a.i and azoxystrobin at $1 \mu \mathrm{g} \mathrm{ml}^{-1}$ a.i. were used in the formulation of the semiselective medium.

Efficacy of mSGSSM on detecting $N$. psidii in soil and diseased tissues. Compared with PDA, mCDM, and mNSM, mSGSSM was the best medium for detection of $N$. psidii in either soil samples artificially infested with $N$. psidii or in tissues of guava plants naturally infected by $N$. psidii (Figs. 1 and 2; Table 6). Colonies of $N$. psidii recovered from soil or diseased tissues were identical with the single-spore culture of $N$. psidii on mSGSSM (Fig. 2C and D). Despite the presence of some contaminants, colonies of $N$. psidii on mSGSSM were morphologically distinguishable from other fungi. $N$. psidii was isolated from diseased limbs and roots collected from different orchards more effectively and consistently on mSGSSM than on the other three media (PDA, mCDM, and mNSM) (Table 6). On PDA and mCDM, the mycelial growth of saprophytes was faster than $N$. psidii; therefore, it was difficult to isolate this pathogen from diseased tissues due to contamination and rapid growth of saprophytes. Although mNSM was more effective than PDA and $\mathrm{mCDM}$ in suppression of saprophytes, the efficiency for recovering $N$. psidii on mSGSSM cultures remained higher than on mNSM cultures (Table 6).

On mSGSSM, the three $N$. psidii isolates Mp-01, Mp-02, and $\mathrm{Mp}-03$ were similar in colony morphology. The $N$. psidii colonies were white and flat, with sparse to abundant aerial mycelia, initially white but becoming orange (25D) when viewed from the top on mSGSSM (Fig. 2C). The color of colonies of $N$. psidii on mSGSSM was light yellow orange (23A) to yellow orange (28C) when viewed from underneath (Fig. 2D). Among the three isolates of $N$. psidii, the mycelial growth of single-spore culture of $\mathrm{Mp}-03$ was significantly $(P<0.05)$ faster than $\mathrm{Mp}-01$ and $\mathrm{Mp}-02$ on $\mathrm{mSGSSM}$ at $30^{\circ} \mathrm{C}$ for 14 days (data not shown).

\section{Discussion}

In this study, a semiselective medium, mSGSSM, was developed for the first time. The basal medium SGM, consisting of azoxystrobin at $1 \mu \mathrm{g} \mathrm{ml}^{-1}$, iprodione at $5 \mu \mathrm{g} \mathrm{ml}^{-1}$, neomycin at 200
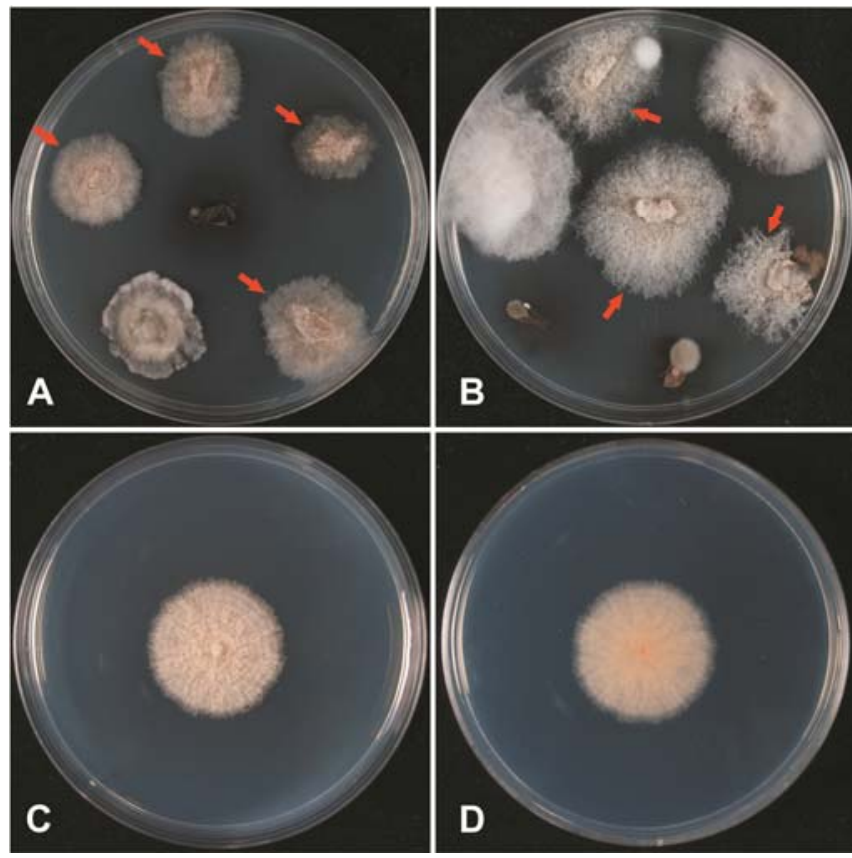

Fig. 2. Isolation of Nalanthamala psidii from $\mathbf{A}$, diseased limbs and $\mathbf{B}$, roots of guava using modified sucrose-glycine semiselective medium (mSGSSM). On mSGSSM, the colony morphology of N. psidii obtained from diseased tissues (A and $B$, arrows) was identical with $\mathbf{C}$ and $\mathbf{D}$, the single-spore culture. The colony was white and flat, with sparse to abundant aerial mycelia initially that turned into white to orange from the top view $(C)$ and light orange yellow from the bottom view (D). The single-spore culture $(C$ and $D)$ was incubated at $30^{\circ} \mathrm{C}$ for 12 days. 
Table 6. Effect of different media on detection of Nalanthamala psidii in different parts of diseased guava trees collected from different locations in Taiwan

\begin{tabular}{|c|c|c|c|c|c|c|c|c|}
\hline \multirow[b]{4}{*}{ Medium $^{z}$} & \multicolumn{8}{|c|}{ Isolation of $N \cdot$ psidii $(\%)^{\mathrm{y}}$} \\
\hline & \multicolumn{3}{|c|}{ Yilan County } & \multicolumn{2}{|c|}{ Yunlin County } & \multirow{3}{*}{$\begin{array}{c}\text { Miaoli County } \\
\text { Zhuolan } \\
\text { L }\end{array}$} & \multirow{2}{*}{\multicolumn{2}{|c|}{$\begin{array}{c}\text { Kaohsiung City } \\
\text { Fengshan }\end{array}$}} \\
\hline & Toucheng & Yuanshan 1 & Yuanshan 2 & Gukeng 1 & Gukeng 2 & & & \\
\hline & $\mathbf{L}$ & $\mathbf{L}$ & $\mathbf{L}$ & $\mathbf{L}$ & $\mathbf{L}$ & & $\mathbf{L}$ & $\mathbf{R}$ \\
\hline PDA & $0.0(0 / 18)$ & $5.6(1 / 18)$ & $0.0(0 / 18)$ & $50.0(9 / 18)$ & $0.0(0 / 18)$ & $0.0(0 / 18)$ & $0.0(0 / 40)$ & $1.3(3 / 226)$ \\
\hline $\mathrm{mCDM}$ & $33.3(6 / 18)$ & $0.0(0 / 18)$ & $0.0(0 / 18)$ & $27.8(5 / 18)$ & $0.0(0 / 18)$ & $0.0(0 / 18)$ & $0.0(0 / 40)$ & $7.5(17 / 226)$ \\
\hline mNSM & $16.7(3 / 18)$ & $16.7(3 / 18)$ & $16.7(3 / 18)$ & $50.0(9 / 18)$ & $33.3(6 / 18)$ & $0.0(0 / 18)$ & $0.0(0 / 40)$ & $3.5(8 / 226)$ \\
\hline mSGSSM & $44.4(8 / 18)$ & $55.6(10 / 18)$ & $5.6(1 / 18)$ & $66.7(12 / 18)$ & $50.0(9 / 18)$ & $11.1(2 / 18)$ & $5.0(2 / 40)$ & $16.8(38 / 226)$ \\
\hline
\end{tabular}

y Location of wilted guava trees collected and tested in this experiment; L = large wilted limb collected from diseased guava plant naturally infected by $N$. psidii and $\mathrm{R}=$ tap and lateral roots of wilted guava plant naturally infected by $N$. psidii. Numbers in parentheses $=$ number of tissues infected by $N$. psidii/total number of tissues sampled from diseased limb or roots.

z $\mathrm{PDA}=$ potato dextrose agar, $\mathrm{mCDM}=$ modified Czapek-Dox medium, $\mathrm{mNSM}=$ modified Nash-Snyder medium, and $\mathrm{mSGSSM}=$ modified sucroseglycine semiselective medium.

$\mu \mathrm{g} \mathrm{ml} \mathrm{g}^{-1}$, and streptomycin at $200 \mu \mathrm{g} \mathrm{ml}^{-1}$, was formulated for the detection of $N$. psidii in diseased guava tissues or in soil. The semiselective medium has low toxicity to $N$. psidii but high toxicity to other fungi such as A. melonis and an Aspergillus sp., Colletotrichum sp., Fusarium sp., Pestalotiopsis sp., and Trichoderma sp. Therefore, isolation of $N$. psidii in artificially infested soil and naturally infected guava limbs and roots was successful on mSGSSM but frequently unsuccessful on PDA, mCDM, or mNSM due to contamination of samples by bacteria or common saprophytic microorganisms in guava orchards. Although some fungal contaminants also grew on mSGSSM, they were readily distinguishable from N. psidii by differences in colony morphology, size, and color on mSGSSM (Figs. 1 and 2).

In the detection test, $N$. psidii could be isolated from the diseased limbs and roots collected from different locations. This study reveals that mSGSSM is more effective than other media (PDA, $\mathrm{mCDM}$, and $\mathrm{mNSM}$ ), with higher rates of $N$. psidii isolated from diseased guava tissues (Table 6). In the diseased plant collected from Kaohsiung, the percentage of $N$. psidii in the roots was higher than in the limb. Previous reports $(6,7)$ indicate that $N$. psidii invades guava trees mainly through wounds created by trimming or pruning, resulting in systemic infection by spread of the pathogen to other parts of tissues, including limbs and roots. The finding in this study is in contrast to the reports of Leu and Kao (6) but is consistent with the reports of Kurosawa (5) and Lim and Manicom (8) that roots are important sites for the infection of $N$. psidii in the field. These conflicting findings in the reports $(5,6,8)$ and the present study indicate that further study is required on the ecology and epidemiology of $N$. psidii. Because the semiselective medium mSGSSM enables the effective recovery of $N$. psidii from both aboveground and belowground tissues of diseased guava trees, it will be a useful tool for etiological, ecological, and epidemiological studies of guava wilt caused by $N$. psidii and for resolving the issue of conflicting reports on primary sites for infection of this pathogen on guava.

\section{Acknowledgments}

This study was funded by the projects 98AS-9.2.3-CI-C2(Z) and 99AS-4.2.2CI-C4 from the Council of Agriculture, Taiwan, R.O.C. We thank C.-T. Lu of the Taiwan Agricultural Research Institute, Wufeng, Taichung, Taiwan, for advice on statistical analyses of the data collected in this study.

\section{Literature Cited}

1. Anonymous. 2011. Index of agricultural production: guava. Page 87 in: Agricultural Statistical Yearbook, Council of Agriculture, Taipei, Taiwan.

2. Dhingra, O. D., and Sinclair, J. B. 1985. Basic Plant Pathology Methods. CRC Press Inc., Boca Raton, FL.

3. Hsieh, S. P. Y., Liang, W. J., Kao, C. W., and Leu, L. S. 1976. Morphology and physiology characters of Myxosporium psidii, the causal organism of guava wilt. Plant Prot. Bull. 18:309-317.

4. Huang, J. W., Sun, S. K., and Ko, W. H. 1983. A medium for chlamydospore formation in Fusarium. Ann. Phytopathol. Soc. Jpn. 49:704-708.

5. Kurosawa, E. 1926. Guava Tachigare Byo. Trans. Nat. Hist. Soc. Formosa 83:47-61. (In Japanese)

6. Leu, L. S., and Kao, C. W. 1979. Artificial inoculation of guava with Myxosporium psidii. Plant Dis. Rep. 63:1077-1079.

7. Leu, L. S., Kao, C. W., Wang, C. C., Liang, W. J., and Hsieh, S. P. Y. 1979. Myxosporium wilt of guava and its control. Plant Dis. Rep. 63:1075-1077.

8. Lim, T. K., and Manicom, B. Q. 2003. Diseases of guava. Pages 275-287 in: Diseases of Tropical Fruit Crops. R. C. Ploetz, ed. CABI Publishing, Wallingford, UK.

9. Nelson, P. E., Toussoun, T. A., and Marasas, W. F. O. 1983. Fusarium Species: An Illustrated Manual for Identification. Pennsylvania State University Press, PA.

10. Schoeman, M. H., Benade, E., and Wingfield., M. J. 1997. The symptoms and cause of guava wilt in South Africa. J. Phytopathol. 145:37-41.

11. Schroers, H. J., Geldenhuis, M. M., Wingfield, M. J., Schoeman, M. H. Yen, Y. F., Shen, W. C., and Wingfield, B. D. 2005. Classification of the guava wilt fungus Myxosporium psidii, the palm pathogen Gliocladium vermoesenii and the persimmon wilt fungus Acremonium diospyri in Nalanthamala. Mycologia 97:375-395. 